\title{
ESTIMATION OF TOTAL PHENOLIC, FLAVONOID CONTENTS AND IN VITRO ANTIOXIDANT ACTIVITY OF MORINGA OLEIFERA VARIETY GROWN IN EGYPT
}

\author{
K. E. Hussain( ${ }^{(1)}$, Sh. N. Draz ${ }^{(1)}$, Samia M. Khalil(1), and A.H.A. Ebrahiem ${ }^{(2)}$ \\ (1) Department of Biochemistry, Faculty of Agriculture, University of Menoufia, Egypt \\ (2) Kaha Central Hospital
}

Received: Jan. 29, 2017

Accepted: Mar. 19, 2017

\begin{abstract}
The present research determined the chemical composition and the antioxidant activity of leaves extracts (aqueous - acetone) of Moringa oleifera variety grown in Egypt. It was found that moringa leaves contain total ash $8.03 \%$, crude lipids $3.14 \%$, crude protein $26.31 \%$, total carbohydrates $44.89 \%$, and crude fiber $17.63 \%$. Total phenolics in leaves aqueous extract were $243.8 \mathrm{mg} / \mathrm{g}$ and total flavonoids were $145.22 \mathrm{mg} / \mathrm{g}$, while in acetone extract total phenolics were $142.51 \mathrm{mg} / \mathrm{g}$ and total flavonoids were $124.64 \mathrm{mg} / \mathrm{g}$. HPLC results showed that moringa leaves contained 23 phenolic compounds and 22 flavonoid contents and the main constituents of both were (e-vanillic, Pyrogallol, Salycilic, Catechin, P-hydroxybenzoic, Ellagic, Alphacoumaric, 3,4,5-trimethoxy-cinnamic, Protocatechuic and Chlorogenic) and (Luteo-6-arabinose8-gloucose, Hesperidin and Rosmarinic) respectively. In comparison with the acetone extract, the aqueous extract showed the highest activity in reducing power assay. Egyptian moringa leaves extracts were found to have antioxidant activity due to their high amount of total phenolics and falvonoids.
\end{abstract}

Key words: Moringa - Phenolic compounds - Flavonoids - antioxidant.

\section{INTRODUCTION}

Herbal medicine is still the most abundant, affordable, reliable, trusted and well understood form of health care in virtually all African villages (Abalaka et al., 2009 ), and $80 \%$ of the population within developing countries uses herbal and other traditional medicines to treat their common ailments (WHO, 2002; Willcox and Bodeker, 2004).

Moringa oleifera Lam. (M. oleifera), commonly known as horse-radish or drumstick tree in English, belongs to family Moringaceae. It is a small sized tree, which is native to South Asia, Africa and Arabia and is used as traditional medicine in many tropical and subtropical countries (Moyo et al., 2011). It is a deciduous tree growing rapidly even in poor soils, well adapted to droughts and able to reach up to $15 \mathrm{~m}$ in height. It is one of the 14 species of genus moringa, which is native to India, Africa, Arabia, Southeast Asia, the Pacific and
Caribbean islands, and South America (Muhl et al., 2011). The flowers and the fruits appear twice each year, and seeds or cuttings are used to propagate the tree. Almost all the parts of $M$. oleifera are used for various ailments in the indigenous medicine of South Asia, including the treatment of diabetes ، hypertension, inflammation and infectious diseases (Verma et al., 2009). Its leaves, pods and flowers are generally consumed for nourishment.

A variety of natural products, including crude extracts and isolated compounds from plants, can induce body weight reduction and prevent diet-induced obesity. Different parts of this plant are used in the indigenous systems of human medicine for the treatment of a variety of human ailments.

The leaf extracts of $M$. oleifera have been reported to exhibit antioxidant activity both in vitro and in vivo due to the high amount of polyphenols such as, phenolics and 
flavonoids components (Atawodi et al., 2010). The leaves were found to be used for the treatment of fever, catarrh, gonorrhea, headache, blood pressure and anxiety. The root, bark and steam are used to treat epilepsy, nervous debility, hysteria, kidney pains, asthma and snake bite. While seeds and seeds oil are used against fever, back pain, rheumatism and bladder troubles (Morton 1991 and Fuglie 2001).

Pharmacological studies have demonstrated that $M$. oleifera known to possess hypoglycemic, hypotensive، antimicrobial, hepatoprotective, immunomodulatory، antioxidant and antitumor activities (Anwar et al., 2007; Sudha et al., 2010; Mahajan and Mehta 2010). These biological activities could be attributed to the presence of secondary plant metabolites present in $M$. oleifera such as phenolics, flavonoids, carotenoids، alkaloids, glycosides, sterols, amino acids, vitamins, and minerals (Auwal et al., 2013). Therefore, the present study was conducted to estimate the major classes of phytochemicals present in the $M$. oleifera variety grown in Egypt, as well as total phenolic and flavonoid contents in $M$. oleifera extracts.

\section{MATERIALS AND METHODS 1. Plant material}

Fresh leaves of $M$ oleifera were collected from Elmedoran, Elmesharak Keblly, Senoris, Faiom, Egypt in February 2014. The leaves were identified in Horticulture department, Faculty of Agriculture, Menoufia University. The leaves were washed and airdried for 24 hours, then dried at $50{ }^{\circ} \mathrm{C}$. The dried samples were grinded into fine powder and kept in refrigerator for analysis.

\section{Determination of chemical composition}

Ash content was determined by ignition of dried sample at $550{ }^{\circ} \mathrm{C}$ until a constant weight according to the Association of Official Analytical Chemists, (AOAC, 2000). Crude fiber was determined according to AOAC, (2000). Total nitrogen was determined (dry basis) according to the modified micro-Kjeldahl method as described by AOAC., (2000). The crude protein contents were calculated using the conversion factor 6.25. Crude lipid was determined according to AOAC., (2000). The total carbohydrate determined by difference $=100-(\%$ protein $+\%$ fat $+\%$ ash).

\section{Preparation of plant extracts}

Of total $(1 \mathrm{Kg})$ dried powdered leaves, $(1 / 2$ $\mathrm{Kg}$ ) was extracted by distilled water and $(1 / 2$ $\mathrm{Kg}$ ) was extracted by acetone at room temperature for 3 days. The resulting extracts were filtered using Whatman no. 1 filter paper and the residues were reextracted by the same process until plant materials were exhausted. The collected filtrates were pooled and evaporated to dryness under reduced pressure to give a semisolid residue, which was then lyophilized to get powder and were stored at - $20{ }^{\circ} \mathrm{C}$ until used. The yields were 99.58 and $74.5 \mathrm{~g}$ per $500 \mathrm{~g}$ of dried powdered leaves of aqueous and acetone extracts respectively.

\section{Determination of total phenolic compounds}

The amount of total phenolics in extracts was determined with the Folin- Ciocalteu reagent. Gallic acid was used as a standard and the total phenolics were expressed as $\mathrm{mg}$ gallic acid equivalents (GAE)/g dry weigh. $10 \mathrm{ml}$ of samples were extracted in methanol. $0.5 \mathrm{ml}$ of each sample and standard were introduced into test tubes and mixed with $2.5 \mathrm{ml}$ of a 10 fold dilute FolinCiocalteu reagent and $2 \mathrm{~mL}$ of $7.5 \%$ sodium carbonate. The tubes were covered tightly and allowed to stand for 30 minutes at room temperature. The absorbance was measured spectrometrically at wavelength 760 nm (Kim et al., 2003).

\section{Determination of total flavonoids compounds \\ The total flavonoids were determined}


using the method reported by Dewanto et al., (2002). Briefly, an aliquot of $250 \mu$ of each extract or a standard solution was mixed with $1.25 \mathrm{ml}$ of deionized water followed by $75 \mu \mathrm{l}$ of a $5 \% \mathrm{NaNO}_{2}$ solution. After $6 \mathrm{~min}, 150 \mu \mathrm{l}$ of $10 \% \quad \mathrm{AlCl}_{3} \cdot 6 \mathrm{H}_{2} \mathrm{O}$ solution was added to each mixture. After 5 min, $0.5 \mathrm{ml}$ of $1 \mathrm{M} \mathrm{NaOH}$ was added, and the total volume was adjusted to $3.0 \mathrm{ml}$ with deionized water. Catechin was used as a standard and absorbance was measured at $510 \mathrm{~nm}$, which was corrected using a blank, the results were expressed as $\mathrm{mg}$ of catechin equivalents (CE)/g dry weight.

\section{Fractionation and quantitative determination of phenolic compounds by HPLC}

Phenolic compounds were fractionated and determined by HPLC according to the method of Goupy et al., (1999) as follow : 5 $\mathrm{g}$ of samples were extracted by methanol and centrifuged at $10000 \mathrm{rpm}$ for $10 \mathrm{~min}$ and supernatant was filtered through a $0.2 \mu \mathrm{m}$ Millipore membrane filter then 1-3 $\mathrm{ml}$ was collected in a vial, using $200 \mu \mathrm{l}$ for injection in HPLC Hewilet Packared (series 1050) equipped with autosamplling injection, solvent degasser, ultraviolet (UV) detector set at $280 \mathrm{~nm}$ and quaternary HP pump (series 1050). Hewlett Packard using a column Alltima C18, $5 \mathrm{~mm}(150 \mathrm{~mm} \times 4.6 \mathrm{~mm}$ Alltech). The column temperature was maintained at $35{ }^{\circ} \mathrm{C}$. Gradient separation was carried out with methanol and acetonitrile as a mobile phase at flow rate of $1 \mathrm{ml} / \mathrm{min}$. Phenolic acid standards from sigma Co. were dissolved in a mobile phase and injected into HPLC. Retention time and peak area were used to calculate phenolic compounds concentration by the data of Hewllet Packared software. The data were reported with convergence limit in triplicate.

\section{Fractionation and quantitative determination of flavonoids by HPLC}

HPLC analyses were performed with Dionex Ultimate 3000 liquid chromatograph
(Germany) with four solvents delivery system quaternary pump (LPG 3400 SD) including a diode array detector (DAD 3000) with $5 \mathrm{~cm}$ flow cell, a manual sample injection valve equipped with a $20 \mu$ loop and Chromeleon 6.8 system manager as data processor. The separation was achieved by a reversed-phase acclaim TM $120 \mathrm{C} 18$ column $(5 \mu \mathrm{m}$ particle size, $4.6 \mathrm{x}$ $250 \mathrm{~mm}$ ). A modified method of Zuo et al., (2002) was used where the mobile phase contains $1 \%$ aq. acetic acid solution (Solvent A) and acetonitrile (Solvent B), the flow rate was adjusted to $0.7 \mathrm{ml} / \mathrm{min}$, the column was thermostatically controlled at $28{ }^{\circ} \mathrm{C}$ and the injection volume was kept at $20 \mu \mathrm{l}$. A gradient elution was performed by varying the proportion of solvent $B$ to solvent $A$. The gradient elution was changed from $10 \%$ to $40 \% \mathrm{~B}$ in a linear fashion for duration of 28 $\mathrm{min}$, from 40 to $60 \% \mathrm{~B}$ in $39 \mathrm{~min}$ and from 60 to $90 \%$ B in 50 min. The mobile phase composition comes back to initial condition (solvent B: solvent A: 10: 90) in 55 min and allowed to run for another $10 \mathrm{~min}$, before the injection of another sample. Total analysis time per sample was $65 \mathrm{~min}$. HPLC chromatograms were detected using a photo diode array UV detector at three different wavelengths $(272,280$ and $310 \mathrm{~nm})$ according to absorption maxima of analysed compounds. Each compound was identified by its retention time and by spiking with standards under the same conditions. The quantification of the sample was done by the measurement of the integrated peak area and the content was calculated using the calibration curve by plotting peak area against concentration of the respective standard sample. The data were reported with convergence limit in triplicate.

\section{In vitro antioxidant activity reducing power assay}

A spectrophotometric method (Oyaizu 1986) was used for the measurement of reducing power. For this determination 2.5 $\mathrm{ml}$ of each extracts were mixed with $2.5 \mathrm{ml}$ 
Hussain, et al.,

of $200 \mathrm{mmol} / \mathrm{l}$ sodium phosphate buffer $(\mathrm{pH}$ 6.6) and $2.5 \mathrm{ml}$ of $1 \%$ potassium ferricyanide. The mixture was incubated at $50{ }^{\circ} \mathrm{C}$ for $20 \mathrm{~min}$. After adding $2.5 \mathrm{ml}$ of $10 \%$ trichloroacetic acid (w/v), the mixture was centrifuged at650 rpm for $10 \mathrm{~min}$. The upper layer $(5 \mathrm{ml})$ was mixed with5 $\mathrm{ml}$ deionized water and $1 \mathrm{ml}$ of $0.1 \%$ of ferric chloride, and the absorbance was then measured at $700 \mathrm{~nm}$. Higher absorbance indicates higher reducing power. Vit.C was used as standard.

\section{RESULTS AND DISCUSSION. \\ 1. Chemical composition of moringa oliefera leaves}

The obtained results in table (1) indicate that $M$ oliefera leaves contain total ash 8.03 $\%$, crude lipid $3.14 \%$, total protein $26.31 \%$, crude fiber $17.63 \%$, and total carbohydrates $44.89 \%$. The results are in accordance with those of Richter, et al., (2003), Oduro, et al., (2008), Moyo, et al., (2011), Simonsohn, (2012) and Borges, et al., (2014) who refer that moringa leaves chemical composition is complex, total ash $7.1 \%$, total lipids $4.7 \%$, crude protein $25.0 \%$, crude fiber $19.9 \%$, and total carbohydrates $43.9 \%$.

\section{Total phenolic compounds and total flavonoids of moringa oliefera leaves extract.}

Plant polyphenols are a major group of compounds acting as primary antioxidants or free radical scavengers. Therefore, it was reasonable to determine the total phenolic and flavonoid contents in the plant extracts. The results obtained are shown in table (2) which indicate that the total phenolics in leaves aqueous extract were $243.8 \mathrm{mg} / \mathrm{g}$ GAE equivalent, while total flavonoids were $145.22 \mathrm{mg} / \mathrm{g}$ catechin equivalent, on the other hand total phenolics and total flavonoids were 142.51 and $124.6 \mathrm{mg} / \mathrm{g}$ for acetone extract respectively. These data agree with those of Siddhuraju and Becker (2003), Iqbal and Bhanger (2006), who found that, the total phenolics results were $83-135 \mathrm{mg} / \mathrm{g}$ and $23-132.3 \mathrm{mg} / \mathrm{g}$. the total phenolics results were $59-140 \mathrm{mg} / \mathrm{g}$ and $69.3-125 \mathrm{mg} / \mathrm{g}$.

Table (1): The chemical composition of moringa leaves (W/W \%)

\begin{tabular}{|l|c|}
\hline \multicolumn{1}{|c|}{ Components } & Percentage (w/w \%) \\
\hline Ash & 8.03 \\
\hline crude lipid & 3.14 \\
\hline Total Protein & 26.31 \\
\hline Crude Fiber & 17.63 \\
\hline Total carbohydrate & 62.52 \\
\hline
\end{tabular}

Table (2): Total phenolic and total flavonoid contents of moringa leaves extracts

\begin{tabular}{|c|c|c|}
\hline Extracts & $\begin{array}{c}\text { Total phenolics } \\
(\mathrm{mg} / \mathrm{g})\end{array}$ & $\begin{array}{c}\text { Total flavonoids } \\
(\mathrm{mg} / \mathrm{g})\end{array}$ \\
\hline aqueous extract & 243.8 & 145.22 \\
\hline Acetone extract & 142.51 & 124.64 \\
\hline
\end{tabular}


3. Quantitative analysis of methoxy-cinnamic, Protocatechuic and phenolic and flavonoids compounds in moringa leaves by HPLC

Phenolic compounds in moringa leaves were analyzed by High Performance Liquid Chromatography (HPLC), and the concentrations of all tested phenolic compounds were given in table (3).

HPLC analysis for the phenolic compounds showed the presence of 23 compounds which were varied in their amounts. It was observed that e-vanillic, Pyrogallol, Salycilic, Catechin, $P-O H-$ Chlorogenic were found in the high level, their amounts were 1366.17, 724.73, 582.68, 438.94, 236.55, 203.37, 189.68, $179.45,167.33$ and $166.26 \mathrm{mg} / 100 \mathrm{~g}$ dry weight respectively. While Caffeine (127.42), Catechol (117.68), Caffeic (115.9), Ferulic (115.67) and Epicatechin (107.82) $\mathrm{mg} / 100 \mathrm{~g}$ dry weight, were found in moderate amounts.

Coumarin, Phenol, Iso-ferulic, Vanillic, Gallic, Cinnamic, 4-aminobenzoic and $P$ coumaric were found in low amounts in the leaves of $(M . O)$ methanolic extract.

Table (3): HPLC analysis of polyphenolics in moringa leaves extract

\begin{tabular}{|c|c|c|}
\hline No & Phenolic compounds & $\mathbf{m g} / \mathbf{1 0 0} \mathbf{g} \mathbf{W}$ \\
\hline $\mathbf{1}$ & Pyrogallol & 724.73 \\
\hline $\mathbf{2}$ & Gallic & 44.58 \\
\hline $\mathbf{3}$ & 4- Amino-benzoic & 12.88 \\
\hline $\mathbf{4}$ & Protocatechuic & 167.33 \\
\hline $\mathbf{5}$ & Catechin & 438.94 \\
\hline $\mathbf{6}$ & Catechol & 117.68 \\
\hline $\mathbf{7}$ & Chlorogenic & 166.26 \\
\hline $\mathbf{8}$ & Epicatechin & 107.82 \\
\hline $\mathbf{9}$ & P-OH-benzoic & 236.55 \\
\hline $\mathbf{1 0}$ & Caffeine & 127.42 \\
\hline $\mathbf{1 1}$ & Caffeic & 115.9 \\
\hline $\mathbf{1 2}$ & Vanillic & 57.81 \\
\hline $\mathbf{1 3}$ & P-coumaric & 11.19 \\
\hline $\mathbf{1 4}$ & Ferulic & 115.67 \\
\hline $\mathbf{1 5}$ & Iso-ferulic & 63.45 \\
\hline $\mathbf{1 6}$ & e-vanillic & 1366.17 \\
\hline $\mathbf{1 7}$ & Ellagic & 203.37 \\
\hline $\mathbf{1 8}$ & Alpha-coumaric & 189.68 \\
\hline $\mathbf{1 9}$ & Benzoic & 77.67 \\
\hline $\mathbf{2 0}$ & Coumarin & 81.34 \\
\hline $\mathbf{2 1}$ & Salycilic & 179.45 \\
\hline $\mathbf{2 2}$ & cinnamic & 582.68 \\
\hline $\mathbf{2 3}$ & & 17.57 \\
\hline & & \\
\hline
\end{tabular}


Hussain, et al.,

Data in table (4) presented the HPLC analysis of flavonoids. It can be seen that, there were 22 Components, Luteo-6arabinose 8-gloucose, Hesperidin and Rosmarinic flavonoids were found in high levels, their amounts were 209.16, 171.05 and $129.58 \mathrm{mg} / 100 \mathrm{~g}$ D.W respectively. While Apig-6-rhamnose-8-glucose, Kaemp3 , (2-p-comaroyl) glucose and Luteolin were found in moderate amounts. their amounts were $69.24,54.69$ and $52.05 \mathrm{mg} / 100 \mathrm{~g}$ D.W respectively. The other compounds i.e. Quercetrin, Apig-6- glucose -8- rhamnose, Hesperetin, Quercetrin-3-O-glucoside, Naringin, Apig.7-O-neohespiroside and Acacetin were found in low levels, their amounts were $31.85,30.12,29.52,28.16$, 25.53, 21.74 and $17.24 \mathrm{mg} / 100 \mathrm{gm}$ D.W respectively

Table (4): HPLC analysis of flavonoids in moringa leaves extract

\begin{tabular}{|c|c|c|}
\hline No & flavonoids & Mg / 100g D.W \\
\hline 1 & Luteo-6-arabinose- 8-glucose & 209.16 \\
\hline 2 & Luteo-6-glocose- 8-arabinose & 3.36 \\
\hline 3 & Apig- 6-rhamnose- 8-glucose & 69.24 \\
\hline 4 & Apig-6-glucose- 8- rhamnose & 30.12 \\
\hline 5 & Naringin & 25.53 \\
\hline 6 & Luteolin & 52.05 \\
\hline 7 & Hesperidin & 171.05 \\
\hline 8 & Rutin & 4.17 \\
\hline 9 & Quercetrin-3-O-glucoside & 28.16 \\
\hline 10 & Rosmarinic & 129.58 \\
\hline 11 & Apig-7-O-neohespiroside & 5.03 \\
\hline 12 & Kamp-3,7-dirhamoside & 13.98 \\
\hline 13 & Apig-7-glucose & 21.74 \\
\hline 14 & Quercetrin & 31.85 \\
\hline 15 & Quercetin & 2.19 \\
\hline 16 & Kaemp-3,(2-p-comaroyl) glucose & 54.69 \\
\hline 17 & Naringenin & 5.67 \\
\hline 18 & Hesperetin & 29.52 \\
\hline 19 & Kampferol & 7.06 \\
\hline 20 & Rhamnetin & 4.68 \\
\hline 21 & Apigenin & 3.64 \\
\hline 22 & Acacetin & 17.24 \\
\hline
\end{tabular}


Eight flavonoids, were detected in very minor amounts including Kamp-3,7dirhamoside, Kampferol, Naringenin, Apig-7O-neohespiroside, Rhamnetin, Rutin, Apigenin and Luteo-6-glocose-8-arabinose at amounts $(13.98,7.06,5.67,5.03,4.68$, 4.17, 3.64 and $3.36 \mathrm{mg} / 100 \mathrm{gm}$ D.W respectively), which agree with those of Vongsak et al., (2013).

\section{Reducing power activity for moringa leaves extracts}

The leaf extracts of $M$. oleifera have been reported to exhibit antioxidant activity both in vitro and in vivo in numerous studies due to their high amount of polyphenols such as, phenolics and flavonoids contents (Verma et al., 2009; Atawodi et al., 2010; Hossain et al., 2012 and Dolly et al., 2013).

Fe (III) reduction is often used as an indicator of electron-donating activity, which is an important mechanism in phenolic antioxidant action (Nabavi et al., 2009). In this assay, the presence of reductants (antioxidants) in the samples would result in the reduction of $\mathrm{Fe}^{+3}$ to $\mathrm{Fe}^{+2}$ by donating an electron.

Data in Fig (1) showed the reducing power of moringa leaves aqueous extracts (2.5\% and $5 \%$ concentration), which were (35.3 and $197.88 \mathrm{mMol}$ Ascorbic Eq), while the reducing power for $2.5 \%$ and $5 \%$ acetone extracts were (22.55 and 147.82 $\mathrm{mMol}$ Ascorbic Eq). These results are in accordance with those of Hossain, et al., (2012) who found that reducing power was (53.925 $\pm 5.25 \mathrm{mMol}$ Ascorbic Eq) for moringa leaves ethanol extract and it was (50.675 $\pm 3.699 \mathrm{mMol}$ Ascorbic Eq) for moringa leaves methanol extract.

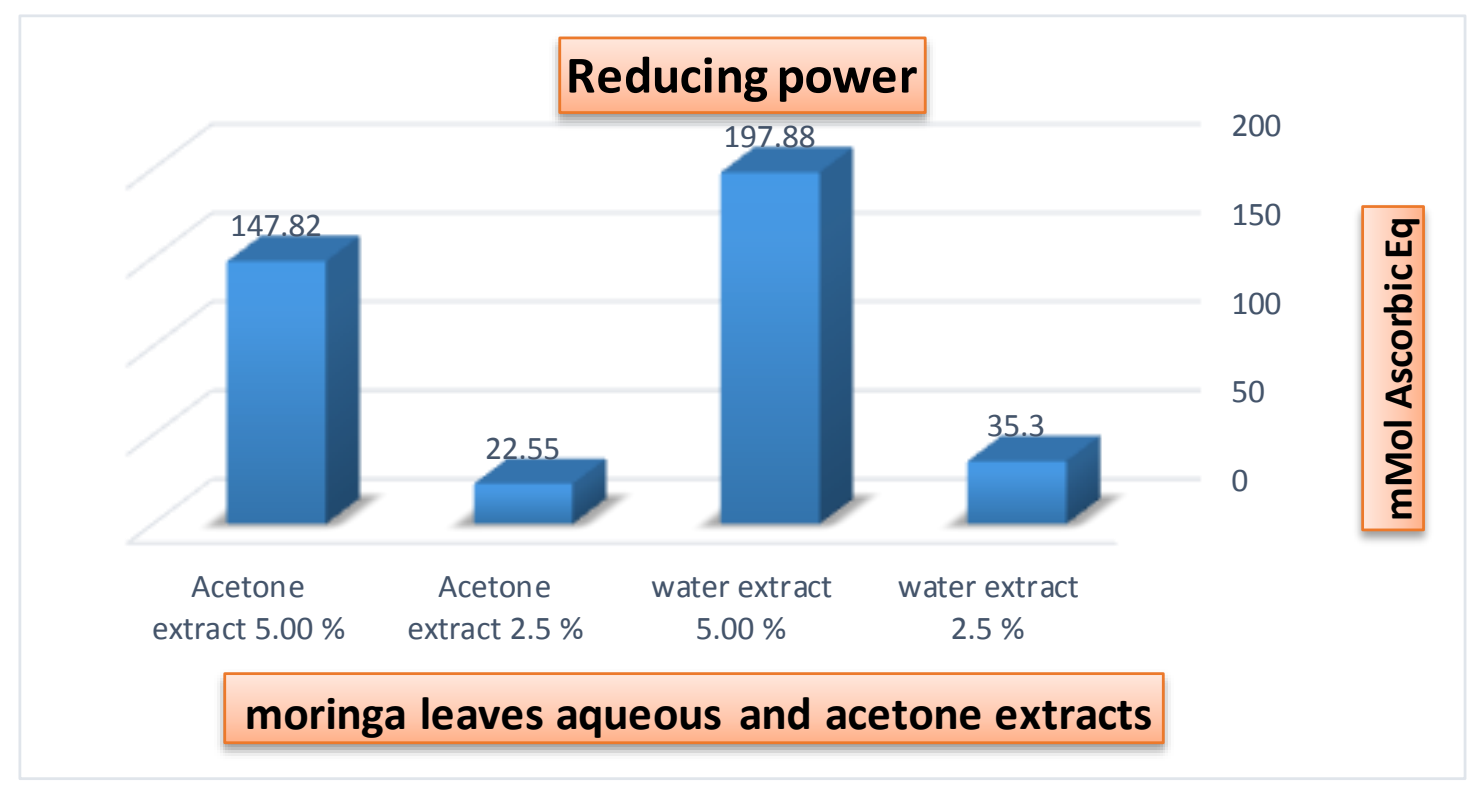

Fig (1): Reducing power activity for moringa leaf extracts. 


\section{CONCLUSION}

The results of our study suggest that leaves extract of $M$. oleifera variety grown in Egypt are rich in phenolic and flavonoid compounds, which means that theses leaves can be used as a natural source of antioxidants to prevent the progression of many diseases. $M$. oleifera leaves extracts also produced marked in-vitro antioxidant activity that justifies its use in traditional system of medicine in Egypt.

\section{REFERENCES}

A.O.A.C. Association of Official Analytical Chemists (2000). Official Methods of Analysis, $17^{\text {th }}$ ed. of the Association of Official Analytical Chemistry, Washington, D.C, MSA.

Abalaka, ME, OS. Olonitola, JA. Onaolapo and HI. Inabo (2009). Evaluation of acute toxicity of Momordica charantia extract, using wistar rats to determine safety levels and usefulness of the plant in ethnochemotherapy.

International Journal of Applied Science; 3: 1-6.

Anwar, F., S. Latif, M. Ashraf and AH. Gilani (2007). Moringa oleifera: a food plant with multiple medicinal uses. Phytother Res.; 21: 17-25.

Atawodi, S.E., JC Atawodi, GA. Idakwo, B. Pfundstein, R. Haubner, G. Wurtele, et al., (2010). J Med Food; 13(3): 710-716.

Auwal, M., A. Tijjani, M. Sadiq, S. Saka, I. Mairiga and A. Shuaibu (2013). Antibacterial and haematological activity of Moringa oleifera aqueous seed extract in Wistar albino rats. Sokoto $\mathrm{J}$ Vet Sci.; 11(1): 28-37.

Borges, EM, MR. Carvalho, VA. Neves, MA. Silva and L. Arantes-Pereira (2014). Chemical characteristics and fractionation of proteins from Moringa oleifera Lam. leaves. Food. Chem.; 14: 5154.

Dewanto, V., X. Wu, KK. Adom and RH. Liu (2002). Thermal processing enhances the nutritional value of tomatoes by increasing total antioxidant activity. $J$. Agric. Food Chem.; 50: 3010-3014.
Dolly, J., KR. Prashant, M. Shikha, C. Sanjukta, S. Surekha and KR. Devendra, (2013). Role of Moringa oleifera in regulation of diabetes-induced oxidative stress. Asian Pac J of Trop Med.; 426432.

Fuglie, LJ. (2001). Combating malnutrition with Moringa. pp. 117-136 in J. Lowell Fugile, ed. The miracle tree: the multiple attributes of Moringa. CTA Publication, Wageningen, the Netherlands.

Goupy, P., M. Hugues, P. Biovin and MJ. Amiot (1999). Antioxidant composition and activity of barley (Hordeum Vuigare) and malt extracts and of isolated phenolic compounds. J. Sci. Food Agric.; 79: 1625 $-1634$.

Hossain, Md, A. Sadika, MdL Aminul, AB. Mohiuddin and S. Mohammad (2012). In vitro antioxidant activity of moringa oleifera leaves, s. J. Pharm. Sci.; 5(I \&2): 41-52.

lqbal, S. and MI. Bhanger (2006). Effect of season and production location on antioxidant activity of moringa oleifera leaves grown in Pakistan. J. Food Compost. Anal.; 19: 544-551.

Kim, DO., SW. Jeong and CY. Lee (2003). Antioxidant capacity of phenolic phytochemicals from various cultivars of plums. Food Chem.; 81:321-326.

Mahajan, SG. and AA. Mehta (2010). Immunosuppressive activity of ethanolic extract of seeds of Moringa oleifera Lam. in experimental immune inflammation. $J$ Ethnopharmacol.; 130(1): 183-186.

Morton, JF. (1991). The horseradish tree, Moringa pterygosperma (Moringaceae) a boon to arid lands. Economic Botany; 45(3): 318-333.

Moyo, B., PJ. Masika, A. Hugo and V. Muchenje (2011). Nutritional characterization of Moringa (Moringa oleifera Lam.) leaves. Afr $J$ Biotech.; 10(60): 12925-12933.

Muhl, QE., Du Toit ES and PJ. Robbertse (2011). Moringa oleifera (horseradish tree) leaf adaptation to temperature regimes. Int J Agric Biol.; 13: 1021-1024. 
Nabavi, SM, MA. Ebrahimzadeh, SF. Nabavi, M. Fazelian and B. Eslami (2009). In vitro Antioxidant and Free radical scavenging activity of Diospyros lotus and Pyrus boissieriana growing. Iran. Phcog. Mag.; 4(18): 122- 126.

Oduro, I., WO. Ellis and D. Owusu (2008). Nutritional potential of two leafy vegetables: Moringa oleifera and Ipomoea batatas leaves. Sci. Res. Essays; 3:057-060.

Oyaizu, M. (1986). Studies on product of browning reaction prepared from glucose amine. Jpn J Nutr.; 07: 307-15.

Richter, N., P. Siddhuraju and K. Becker (2003). Evaluation of nutritional quality of moringa (Moringa oleifera Lam.) leaves as an alternative protein source for Nile tilapia (Oreochromis niloticus L.). Aquaculture; 217: 599-611.

Siddhuraju, P. and K. Becker (2003). Antioxidant properties of various solvent extracts of total phenolic constituents from three different agro climatic origins of drumstick tree (Moringa oleifera Lam.). Journal of Agriculture and Food Chemistry; 15: 2144-2155.

Simonsohn, B. (2012). Moringa. Espana. Andreas Walter Kraus, Espana.
Sudha, P., SM. Asdaq, SS. Dhamingi and GK. Chandrakala (2010). Immunomodulatory activity of methanolic leaf extract of Moringa oleifera in animals. Indian J Physiol Pharmacol.; 54(2): 133-140.

Verma, AR., M. Vijaykumar, CS. Mathela and CV. Rao (2009). In-vitro and in-vivo antioxidant properties of different fractions of Moringa oleifera leaves. Food Chem Toxicol.; 47: 2196-2201.

Vongsak, B., P. Sithisarn, S. Mangmool, S. Thongpraditchote, Y. Wongkrajang and W. Gritsanapan (2013). Maximizing total phenolics, total flavonoids contents and antioxidant activity of Moringa oleifera leaf extract by the appropriate extraction method. Ind. Crop. Prod.; 44: 566-571.

WHO (2002). Traditional Medicine Strategy 2002-2005. WHO, Geneva.

Willcox, ML. and G. Bodeker (2004). Traditional herbal medicines for malaria. BMJ 329،1156L 9, PMID: 15539672 doi:10. 1136/bmj. 329. 7475.1156.

Zuo, Y., H. Chen and Y. Deng (2002). Simultaneous Determination of Catechins, Caffeine and Gallic acids in Green, Oolong and Black tea using HPLC with a Photodiode Array Detector. Talanta; 57: 307-316. 


\section{تقدير الفينولات الكلية ومحتوى الفلافونات والنشاط المضاد للأكسدة معمليا فى

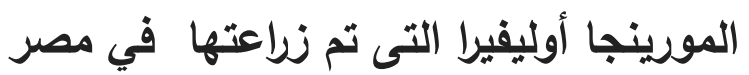

كمال إمام حسين(1) ، شعبان نجم دراز (1) ، سامية محمود خليل(1) ،

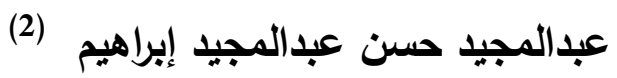

(1) قسم الكيمياء الحيوية - كلية الزراعة - جامعة المنوفية

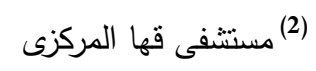

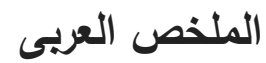

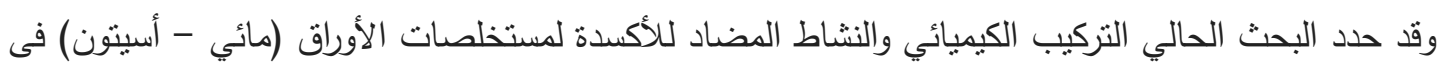

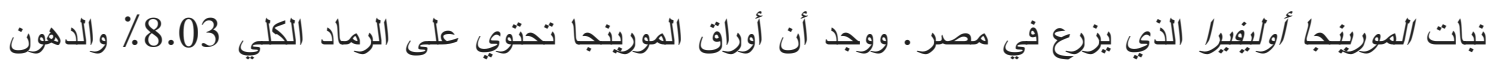
الخام 3.14٪ والبروتين الخام 26.31٪ والكربوهيدرات الكلية 44.89٪ والألياف الخام الفينولات في الأوراق المستخلص المائي 243.8 ملجرام / جرام وكان مجموع الفلافونويدات 145.22 ملجرام / جرام ، بينما بلغ مجموع الفينوليات 142.51 ملجرام / جرام وكان مجموع الفلافونويد 124.64 ملجرام / جرام. وأظهرت نتائج HPLC أن أوراق المورينجا تحتوي على 23 مركب فينولى و 22 مركب فلافونى وكانت المكونات الرئيسية لكل من (الفاليين، بيروجالول، ساليسيليك، كاتشين، P- هيدروكسي بنزويك، إلاجيك، ألفا-كوماريك،

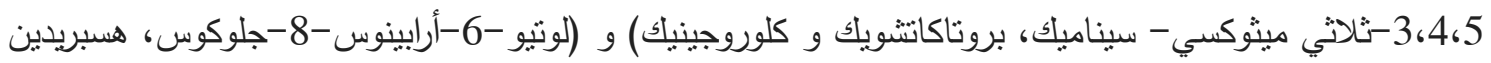
و روزمارينيك) على التوالي. وبالمقارنة مع مستخلص الأسيتون، أظهر المستخلص المائي أعلى نشاط في تقائليل مقايسة الطاقة. نم إثبات أن أوراق المورينجا المصرية ذات نشاط مضاد للأكسدة نظرا لوجود كمية عالية من لنان الفينولات الكلية والفالفونويدات. 